Kulykovska S. Assessment of the level of preinduction and physical fitness of young people in the process of physical education. Theory and Methods of Physical education and sports. 2020; 1 : 75-80 DOI: $10.32652 /$ tmfvs.2020.1.75-80

\title{
ОЦІНКА РІВНЯ ДОПРИЗОВНОЇ ТА ФІЗИЧНОї ПІДГОТОВЛЕНОСТІ ЮНАКІВ У ПРОЦЕСІ ФІЗИЧНОГО ВИХОВАННЯ
}

\section{Світлана Куликовсъка}

Національний університет фізичного виховання і спорту України, Київ, Україна

\begin{abstract}
Анотація. Стаття присвячена визначенню основних напрямів підвищення рівня допризовної та фрізичної підготовленості юнаків старших класів у процесі фрізичного виховання. Показано, що актуальним $є$ всебічна підготовка учнів до строкової військової служби, спрямована на подальший фрізичний, вольовий, інтелектуальний, професійний, моральний розвиток особистості для підвищення ефективності військово-патріотичного виховання, в тому числі і на уроках фрізичної культури. Мета. Визначення рівня допризовної та фрізичної підготовленості юнаків старших класів у процесі фрізичного виховання. Методи. Аналіз даних науково-методичної літератури, нормативно-правових, програмно-методичних документів, узагальнення досвіду передової педагогічної практики.
\end{abstract}

Результати. Розглянуто завдання предмета «Захист Вітчизни» - формування у юнаків високого рівня готовності до виконання вимог сучасної військової діяльності, всебічна підготовка до строкової військової служби, спрямована на подальший фрізичний, вольовий, інтелектуальний, професійний, моральний розвиток особистості. Виявлено, що більшість обстежених учнів старших класів мали достатній рівень розвитку швидкісних здібностей, середній рівень розвитку витривалості та достатній рівень розвитку швидкісно-силових якостей. Результати оцінювання рівня допризовної підготовки показали, що половина юнаків $(51,8$ \%) мають середній рівень вогневої підготовки за результатами виконання тесту «Приготування до стрільби і ведення вогню з автомата». Результати тестування виявили високий рівень тактичної підготовки старшокласників за результатами тесту «Визначення сторін горизонту». Однак у тесті «Рух за азимутом», який теж оцінює рівень тактичної підготовки, ми бачимо значну кількість учнів $(55,6$ \%) з достатнім і низьким рівнями. Результати тестування «Одягання респіратора Р-2» для оцінювання рівня цивільного захисту свідчать, що більшість школярів $(40,7 \%)$ мали середній рівень цивільного захисту. Тест «Накладання шини з підручного матеріалу на передпліччя» свідчить про досить високий рівень медико-санітарної підготовленості юнаків. Ключові слова: юнаки, фізична підготовленість, допризовна підготовленість.

\section{Svitlana Kulykovska \\ ASSESSMENT OF THE LEVEL OF PREINDUCTION AND PHYSICAL FITNESS OF YOUNG PEOPLE IN THE PROCESS OF PHYSICAL EDUCATION}

\begin{abstract}
The article is devoted to definition of the main directions of increasing the level of preinduction and physical fitness of senior school children in the process of physical education. It is shown that the comprehensive preparation of pupils for military service, aimed at further physical, volitional, intellectual, professional, moral development of personality to increase the effectiveness of military-patriotic education, including at physical education lessons, is important. Objective. Determining the level of pre-service and physical fitness of senior school children in the process of physical education. Methods. Analysis of data of scientific and methodical literature, normative-legal, program-methodical documents, generalization of experience of advanced pedagogical practice. Results. The task of the subject «Defense of the Fatherland» is considered - formation of a high level of readiness in young persons to meet the requirements of modern military activity, comprehensive preparation for military service, aimed at further physical, volitional, intellectual, professional, moral development. It was found that most of the surveyed senior school children had a sufficient level of development of speed abilities, an average level of endurance development and a sufficient level of development of speed and strength qualities. The results of the assessment of the level of preinduction training showed that half of the young men $(51.8 \%)$ have an average level of fire training according to the results of the test «Preparation for shooting and firing from assault rifle». The test results revealed a high level of tactical training of senior school children according to the results of the test «Determining the sides of the horizon». However, in the Azimuth Movement test, which also assesses the level of tactical training, we see a significant number of pupils $(55.6 \%)$ with sufficient and low levels. The results of the P-2 respirator test to assess the level of civil protection show that the majority of schoolchildren $(40.7 \%)$ had an average level of civil protection. The test «Applying a tire of improvised material on the forearms» shows a fairly high level of medical fitness of young men.
\end{abstract}

Keywords: young men, physical fitness, preinduction readiness. 
Вступ. Фізичне виховання - важливий засіб фізичного, соціального та духовного розвитку учнівської молоді. Основною метою навчального предмета «Фізична культура» є: формування в учнів стійкої мотивації до збереження свого здоров'я, фізичного розвитку та фізичної підготовки; гармонійний розвиток природних здібностей та психічних якостей; використання засобів фізичного виховання в організації здорового способу життя [6]. Уроки фізичної культури відіграють велику роль у фізичній підготовці юнаків до військової служби. На заняттях із фізичної культури формуються якості, необхідні військовослужбовцю: висока працездатність, витривалість, чітка координація і точність рухів [3, 7, 12].

Духовна порожнеча, розмитість і невизначеність ідейних орієнтирів, незадовільна фізична підготовка, низький рівень соціальних мотивів готовності боронити свою Вітчизну - ось що маємо в результаті недооцінки цих вагомих напрямів роботи 3 молоддю [1]. Тому особливо актуальною є допризовна підготовка сучасної молоді. Для вирішення цих питань розроблено нову програму предмета «Захист Вітчизни» на основі вимог Конституції та законів України про захист Вітчизни і Державного стандарту базової і повної загальної середньої освіти [5].

Проблему фізичної та допризовної підготовки досить грунтовно висвітлено в науковій літературі. Розроблено заходи, що стосуються питань допризовної підготовки і військово-патріотичного виховання у школі [1], визначено педагогічні умови формування готовності старшокласників до служби в Збройних силах України [2], особливості виховання старшокласників на військовокозацьких традиціях у процесі допризовної підготовки [3], особливості організації і проведення навчально-виховного процесу з допризовної підготовки в школі [4], розроблено методики фізичного виховання різних груп населення [8, 9, 11].

Сьогодні можна констатувати наявність великої кількості досліджень у галузі фізичного виховання, що стосуються фізичної підготовки та допризовної підготовки учнів [4, 10]. Разом з тим, практика свідчить, що зусилля, які докладаються закладами загальної середньої освіти до покращення фізичної та допризовної підготовки, недостатньо ефективні. Необхідно відмітити той факт, що у закладах загальної середньої освіти звертається недостатня увага на формування у юнаків високого рівня готовності до виконання вимог сучасної військової діяльності. Тому актуальним є всебічна підготовка учнів до строкової військової служби, спрямована на подальший фізичний, вольовий, інтелектуальний, професійний, моральний розвиток особистості для підвищення ефективності військово-патріотичного виховання, в тому числі і на уроках фізичної культури.

Дослідження виконано згідно 3 планом наукової роботи НУФВСУ на 2016-2020 рр. відповідно
Таблиця 1 - Середньостатистичні значення результатів оцінювання рухових здібностей юнаків 16-17 років

\begin{tabular}{|l|c|c|}
\hline \multicolumn{1}{|c|}{ Нормативи } & $\begin{array}{c}\text { Статистичні } \\
\text { показники }\end{array}$ & $\mathbf{n = 2 7}$ \\
\hline \multirow{2}{*}{ Біг 100 м, с } & $x$ & 15,36 \\
\cline { 2 - 3 } & $\mathrm{S}$ & 0,54 \\
\hline Рівномірний біг 1500 м, хв, с & $x$ & 7,01 \\
\cline { 2 - 3 } & $\mathrm{S}$ & 0,45 \\
\hline Стрибок у довжину з місця, см & $x$ & 169,59 \\
\cline { 2 - 3 } & $\mathrm{S}$ & 12,80 \\
\hline
\end{tabular}

до теми кафедри теорії і методики фізичного виховання «Теоретико-методичні основи вдосконалення програмно-нормативних засад фізичної підготовки дітей, підлітків і молоді» (номер держреєстрації 0116U001626).

Мета дослідження - визначення рівня допризовної та фізичної підготовленості юнаків старших класів у процесі фізичного виховання.

Методи дослідження: аналіз даних науковометодичної літератури, нормативно-правових, програмно-методичних документів, узагальнення досвіду передової педагогічної практики; методи оцінювання фізичної підготовленості, допризовної підготовленості, методи статистичної обробки даних.

Результати дослідження та їх обговорення. У дослідженні взяли участь 27 юнаків 11-х класів м. Києва. Рівень фізичної підготовленості обстежених визначали за результатами рухових тестів: «біг 100 м», «біг 1500 м», «стрибок у довжину 3 місця» (табл. 1).

У ході оцінювання рівня розвитку бистроти (за результатами тесту «біг 100 м») виявлено, що $40,8 \%$ учнів мають достатній рівень, 25,9\% - середній, 22,2 \% - низький і лише 11,1 \% - високий рівень розвитку швидкісних здібностей.

Результати аналізу рівня розвитку витривалості у обстежених свідчать про середній рівень розвитку цієї якості у 37,1 \% юнаків, 29,6 \% мають низький рівень, 25,9\% - достатній та 7,4\% - високий рівень. У ході дослідження було встановлено, що більшість обстежених юнаків мають достатній рівень розвитку швидкісно-силових якостей (за результатами тесту «стрибок у довжину 3 місця»), 29,6 \% притаманний середній, 18,5 \% мають низький рівень і $14,8 \%$ - високий.

Головною метою вивчання предмета «Захист Вітчизни» протягом існування незалежної України є розвиток особистості учнів та формування їх готовності до участі в захисті Вітчизни та дій у надзвичайних ситуаціях.

Зміст предмета «Захист Вітчизни» складається 3 семи розділів: «Військово-історичні, правові та політичні основи захисту Вітчизни», «Загальновійськова підготовка», «Вогнева підготовка», 
«Тактична підготовка», «Прикладна фізична підготовка», «Основи цивільного захисту», «Основи медико-санітарної підготовки».

Завдання предмета «Захист Вітчизни» - формування у юнаків високого рівня готовності до виконання вимог сучасної військової діяльності, всебічна підготовка до строкової військової служби, спрямованої на подальший фізичний, вольовий, інтелектуальний, професійний, моральний розвиток особистості, формування у юнака якостей справжнього чоловіка. Згідно 3 «Концепцією допризовної підготовки і військово-патріотичного виховання молоді», схваленою Указом Президента України від 25 жовтня 2002 р. № 948/2002, підготовка до захисту Вітчизни включається до інваріантної частини навчального плану професійнотехнічних і загальноосвітніх навчальних закладів.

Слід зазначити, що важливою умовою успішності занять 3 предмета «Захист Вітчизни» є висока дисциплінованість, організованість, відповідальність учнів. На заняттях стосунки між учнями i викладачем, а також учнів між собою підтримуються на зразок стосунків між військовослужбовцями Збройних сил України.

Для оцінювання рівня допризовної підготовки нами було використано такі тести: «Приготування до стрільби і ведення вогню з автомата», «Визначення сторін горизонту», «Рух за азимутом», «Одягання респіратора Р-2», «Накладання шини 3 підручного матеріалу на передпліччя» .

Тест «Приготування до стрільби і ведення вогню 3 автомата» використовували для визначення рівня вогневої підготовки юнаків старших класів. Учень знаходився у вихідному положенні, автомат тримав «на ремінь», магазин у сумці для магазинів. За командою керівника роздавач видав п'ять навчальних патронів. Учень заряджав магазин i укладав його у сумку. За командою «До бою!» виконував норматив: займав місце для стрільби, заряджав зброю, готувався до ведення вогню і доповідав: «Такий-то до бою готовий!». Стрільбу по мішенях виконували: на 25 м 3 положення стоячи, на 50 м 3 положення сидячи, на 100 м 3 положення лежачи. Для виконання стрільби надано: один патрон на 25 м, два патрони на 50 м, два патрони на 100 м. Дії після команди «Вогонь» виконуються без урахування часу.

Результати виконання тесту свідчать, що 51,8 \% юнаків мають середній рівень вогневої підготовки, попадання в мішені - три-чотири патрони та допустили не більше двох помилок. Чверть юнаків мають достатній рівень вогневої підготовки $(25,9 \%)$, попадання в мішені - два-три патрони та допустили не більше трьох помилок. Високий рівень вогневої підготовки притаманний 14,9 \% юнаків, які виконали тест правильно, чітко, з попаданням у мішені чотирьох-п'яти патронів. Низький рівень мають 7,4 \% юнаків, які допустили понад три помилки, порушили заходи безпеки під час поводження зі зброєю, попадання в мішені - 1-2 патрони.

Наявність юнаків 3 низьким та достатнім результатами під час виконання тесту «Приготування до стрільби і ведення вогню з автомата» може бути наслідком недостатньої кількості годин, відведених на тренування та вогневу підготовку.

Тест «Визначення сторін горизонту» було використано для оцінювання рівня тактичної підготовки юнаків старших класів. Учень 3 компасом або годинником у руці знаходився у вказаній точці місцевості. За командою керівника «До орієнтування приступити!» визначав сторони горизонту і доповідав «Готово!»

Результати виконання тесту свідчать, що юнаки старших класів переважно виконують цей тест 3 високим результатом. Так, без помилок протягом 22-26 с визначають сторони горизонту 74 \% юнаків, які відповідно мають високий рівень. Середній рівень мають 14,9 \% юнаків - вони виконали завдання протягом 24-28 с і допустили помилку. Достатній рівень показали 7,4 \% юнаків - виконання тесту зайняло 22-26 с, але допустили дві помилки. Низький рівень тактичної підготовки мав лише один юнак, допустивши більше двох помилок та виконавши завдання з результатом більше $24 \mathrm{c}$.

Наявність юнаків старшого шкільного віку 3 низьким та достатнім рівнями тактичної підготовки може свідчити про їх неуважність під час виконання цього тесту, що призвело до появи значної кількості помилок, та як наслідок, - низьких результатів.

Для оцінювання рівня тактичної підготовки було використано тест «Рух за азимутом». Юнакові видавалася схема (таблиця) даних для руху за азимутом, на якій вказано вихідний та кінцевий пункти, три-чотири проміжних орієнтири, магнітні азимути та відстані між ними в метрах. Довжина маршруту не менше 2 км. Дотримуючись маскування, пішим порядком учень повинен був вийти до кінцевого пункту. Час враховувався від видачі схеми до виходу у кінцевий пункт.

Результати тесту свідчать, що високий рівень тактичної підготовки був у 33,4 \% юнаків, які виконали завдання протягом 24-28 хв, середній рівень - у 25,9 \%, які виконали завдання протягом 30-34 хв, у 22,2 \% відмічено достатній рівень виконали завдання протягом 36-40 хв, у 18,5\% юнаків - низький рівень - на виконання завдання у них пішло більше 42 хв.

Тест «Визначення сторін горизонту» виявив загалом високий рівень тактичної підготовки юнаків $(74 \%)$, та показав, що вони добре володіють навичками роботи з компасом. Однак у тесті «Рух за азимутом», який теж оцінює рівень тактичної підготовки, ми бачимо значну кількість юнаків $(55,6$ \%) з достатнім і низьким рівнями. Результат цього тесту залежить не тільки від ступеня володіння компасом і навичками орієнтування, а й від 
рівня загальної витривалості, оскільки під час виконання цього тесту юнаки мали подолати дистанцію більше 2 км, при цьому було встановлено ліміт часу.

Оцінювання рівня цивільного захисту здійснювали за результатами тесту «Одягання респіратора Р-2». За раптовою командою «Респіратор одягнути!», учні одягали респіратори. Час відраховували 3 моменту подачі команди до відновлення дихання.

Результати тестування свідчать, що більшість юнаків (55,6 \%) мали високий рівень цивільного захисту - вони виконали тест менше ніж за 11,4 с. Значна кількість (40,7 \%) юнаків виконали тест за 11,7-12,4 с, що свідчить про середній рівень цивільного захисту. Лише один юнак показав низький результат - більше 13,7 c.

Визначення рівня медико-санітарної підготовленості проводили за результатами виконання тесту «Накладання шини 3 підручного матеріалу на передпліччя». Учень знаходився біля «пораненого», перев' язочний матеріал і шина в руках або поряд 3 ним. За командою «Шину накласти!» учень накладає шину. Виконання нормативу закінчується підвішуванням руки на хустку (бинт, ремінь).

Юнаків 3 низьким рівнем медико-санітарної підготовленості виявлено не було, високий рівень відмічено у 22,2 \% юнаків, які виконали завдання без помилок менше ніж за 3 хв, середній рівень зафіксовано у 40,3 \%, які допустили одну помилку та виконали тест у діапазоні часу - від 3 хв 10 с до 3 хв 30 с, достатній рівень спостерігався у 37,1 \% юнаків, які припустилися двох помилок та витратили на завдання до 4 хв. Результати цього тесту свідчать про досить високий рівень медикосанітарної підготовленості юнаків, однак їх можна покращити, якщо виконувати тест не тільки технічно правильно, а й швидко.

Таким чином, результати оцінювання рівня допризовної підготовки показали, що 51,8 \% юнаків мають середній рівень вогневої підготовки за результатами виконання тесту «Приготування до стрільби і ведення вогню з автомата». Результати тестування виявили високий рівень тактичної підготовки юнаків старшого шкільного віку за результатами тесту «Визначення сторін горизонту», проте у тесті «Рух за азимутом», який теж оцінюе рівень тактичної підготовки, бачимо значну кількість юнаків $(55,6$ \%) 3 достатнім і низьким рівнями. Результати тестування «Одягання респіратора Р-2» для визначення рівня цивільного захисту свідчать, що більшість юнаків (40,7 \%) мали середній рівень цивільного захисту, «Накладання шини 3 підручного матеріалу на передпліччя» про досить високий рівень медико-санітарної підготовленості.

Метою підвищення рівня допризовної підготовленості юнаків є: визначення основних напрямів удосконалення допризовної підготовки і військовопатріотичного виховання молоді; забезпечення єд- ності навчання, виховання, розвитку і психологічної підготовки молоді до захисту Вітчизни; вироблення єдиних поглядів на проблему виховання патріота і громадянина; визначення ролі державних органів в організації та проведенні допризовної підготовки і військово-патріотичного виховання молоді; удосконалення педагогічних форм i методів навчання молоді основ військової справи; формування у молоді високої патріотичної свідомості, національної гідності, готовності до виконання громадянського і конституційного обов' язку щодо захисту національних інтересів України; узгодження дій міністерств, інших центральних та місцевих органів виконавчої влади, органів місцевого самоврядування щодо цілеспрямованої підготовки молоді до захисту Вітчизни; створення системи шефських зв'язків військових частин і вищих військових навчальних закладів 3 навчальними закладами, в яких проводиться допризовна підготовка, взаємодії з ветеранськими та іншими громадськими організаціями патріотичного спрямування.

Для підвищення рівня допризовної підготовленості необхідним є вивчення історії українського війська; ознайомлення із законодавством з військових питань, із структурою і завданнями Збройних сил України та інших військових формувань; вивчення основ цивільної оборони України.

3 метою розвитку заінтересованості юнаків у вивченні основ військової справи, підвищення рівня їхньої фізичної та психологічної підготовленості проводяться всеукраїнські і регіональні спартакіади, змагання з військово-прикладних видів спорту, ігри оборонно-масової і військовопатріотичної спрямованості.

Основними напрямами підвищення рівня допризовної підготовленості учнів є: ознайомлення молоді 3 основними положеннями Конституції України про захист Вітчизни, Законів України «Про оборону України», «Про загальний військовий обов'язок i військову службу», інших нормативно-правових актів з питань оборони, військового будівництва та проходження військової служби; усвідомлення молоддю свого обов'язку в разі виникнення загрози суверенітету та територіальній цілісності України; набуття знань про функції Збройних сил України та інших військових формувань, їх характерні особливості; засвоєння основ військової справи, цивільної оборони і медико-санітарної підготовки; здійснення психологічної підготовки до військової служби.

Висновки. Більшість обстежених юнаків старших класів мали достатній рівень (40,8 \%) розвитку швидкісних здібностей - за результатами бігу на 100 м, середній $(37,1 \%$ ) рівень розвитку витривалості - за результатами бігу 1500 м та достатній $(37,1 \%)$ рівень розвитку швидкісно-силових якостей - за результатами тесту «стрибок у довжину 3 місця». 
Результати оцінювання рівня допризовної підготовленості показали, що кожен другий юнак має середній рівень вогневої підготовленості за результатами виконання тесту «Приготування до стрільби і ведення вогню 3 автомата», високий рівень тактичної підготовленості - за результатами тестів «Визначення сторін горизонту» та «Рух за азимутом», середній рівень цивільного захисту - за результатами тесту «Одягання респіратора $\mathrm{P}-2$ » та середній рівень медико-санітарної підготовленості - за результатами тесту «Накладання шини 3 підручного матеріалу на передпліччя» .

Перспективи подалыших досліджень полягають у розробці комплексної оцінки рівнів фізичної та допризовної підготовленості юнаків старшого шкільного віку.

Конфлікт інтересів. Автор заявляє, що відсутній будь-який конфлікт інтересів.

\section{Література}

1. Єдинак ГА, Клименко ММ, Мисів ВМ. Навчальний предмет «Захист вітчизни»: довідковий посібник за заг. ред. Єдинака ГА. Камянець-Подільський: ПП Мошак М. І. 2004. 296 с.

2. Івашковський ВВ. Педагогічні умови фрормування готовності старшокласників до служби в Збройних Силах України [автореферат]. Київ: 2002. 22 с.

3. Кириченко ОВ. Виховання старшокласників на військово-козацьких традиціях у процесі допризовної підготовки: Комплексна навчально-виховна програма та методичні рекомендації щодо її реалізації. Донецьк: Юго-Восток. 2005. 212 с.

4. Коробов МГ. Організація і проведення навчально-виховного процесу з допризовної підготовки в школі: методичний посібник. Кіровоград: КЗ «КОІППО імені Василя Сухомлинського»; 2015. 160 с.

5. Навчальна програма «Захист Вітчизни» для навчальних закладів системи загальної середньої освіти (рівень стандарту). Електронний ресурс: https://mon.gov.ua/...10-11.../zaxist-vitchizni.-riven-standartuzatverdzhena13.12.2017.

6. Круцевич ТЮ, редактор. Теорія і методика фрізичного виховання: підруч. для студ. ВНЗ фріз. виховання і спорту. Київ: Олімпійська література; 2017. Т. 2. 448 с.

7. Dias Ingrid. Influence of exercise order on maximum strength in untrained young men. Journal of Science and Medicine in Sport. 2010; 13: 65-69. DOI: https://doi.org/10.1016/j.jsams.2008.09.003

8. Kyröläinen H, Santtila M, Nindl BC, Vasankari T. Physical fitness profiles of young men: associations between physical fitness, obesity and health. Sports Med. 2010; 40(11):907-20. doi: 10.2165/11536570-000000000-00000.

9. Taanila Henri. Low physical fitness is a strong predictor of health problems among young men: a follow-up study of 1411 male conscripts. BMC Public Health 2011. 11:590. https://doi.org/10.1186/1471-2458-11-590

10. Tanskanen Minna M. Heikki Kyröläinen, Matti Santtila, Tuija Tammelin. Estimation of aerobic fitness among young men without exercise test. Volume 7: Issue 1. First Online: 17 Aug 2015. DOI: https://doi.org/10.1515/bhk2015-0016.

11. Tchamo Mario Eugénio. Physical Fitness and birth Weight in young men. Rev Bras Med Esporte vol.22 no.1 São Paulo Jan./Feb. 2016. http://dx.doi.org/10.1590/1517-869220162201147126.

12. VojciechowskiAudrin Said. Effects of exergame training on the health promotion of young adults. Fisioterapia em Movimento On-line version ISSN 1980-5918. Fisioter. mov. vol.30 no.1 Curitiba Jan./Mar. 2017 http://dx.doi. org/10.1590/1980-5918.030.001.ao06.

\section{Literature}

1. ledynak HA, Klymenko MM, Mysiv VM. The subject «Defense of the Fatherland»: a reference manual edited by ledynak HA. Kamianets-Podilskyi: PP Moshak M. I. 2004. 296 p.

2. Ivashkovskyi VV. Pedagogical conditions of formation of readiness of senior pupils for service in the Armed Forces of Ukraine [author's abstract]. Kyiv: 2002. 22 p.

3. Kyrychenko OV. Education of senior school children according to military-Cossack traditions in the process of pre-conscription training: Comprehensive educational program and guidelines for its implementation. Donetsk: South-East. 2005. 212 p.

4. Korobov $\mathrm{MH}$. Organization and carrying out of educational process on pre-conscription preparation at school: methodical manual. Kirovograd: KZ «KOIPPO imeni Vasyl Sukhomlynskyi»; 2015. 160 p.

5. Curriculum «Defense of the Fatherland» for educational institutions of general secondary education (standard level). Electronic resource: https://mon.gov.ua/...10-11.../zaxist-vitchizni.-riven-standartu-zatverdzhena13.12.2017.

6. Krutsevych TI. Theory and methods of physical education: textbook for students of physical education and sport students. Kyiv: Olimpiyska literatura; 2017. Vol. 2. 448 p.

7. Dias Ingrid. Influence of exercise order on maximum strength in untrained young men. Journal of Science and Medicine in Sport. 2010; 13: 65-69. DOI: https://doi.org/10.1016/j.jsams.2008.09.003.

8. Kyröläinen H, Santtila M, Nindl BC, Vasankari T. Physical fitness profiles of young men: associations between physical fitness, obesity and health. Sports Med. 2010; 40(11):907-20. doi: 10.2165/11536570-000000000-00000. 
9. Taanila Henri. Low physical fitness is a strong predictor of health problems among young men: a follow-up study of 1411 male conscripts. BMC Public Health 2011. 11:590. https://doi.org/10.1186/1471-2458-11-590.

10. Tanskanen Minna M. Heikki Kyröläinen, Matti Santtila, Tuija Tammelin. Estimation of aerobic fitness among young men without exercise test. Volume 7: Issue 1. First Online: 17 Aug 2015. DOI: https://doi.org/10.1515/bhk2015-0016.

11. Tchamo Mario Eugénio. Physical Fitness and birth Weight in young men. Rev Bras Med Esporte vol.22 no.1 São Paulo Jan./Feb. 2016. http://dx.doi.org/10.1590/1517-869220162201147126.

12. VojciechowskiAudrin Said. Effects of exergame training on the health promotion of young adults. Fisioterapia em Movimento On-line version ISSN 1980-5918. Fisioter. mov. vol.30 no.1 Curitiba Jan./Mar. 2017 http://dx.doi. org/10.1590/1980-5918.030.001.ao06.

Надійшла 21.02.2020

\section{Інформація про автора}

Куликовська Світлана Миколаївна, https:orcid.org/0000-0001-7061-5607, kulikovskayasveta@gmail.com,

Національний університет фізичного виховання і спорту України, 03150, Київ, вул. Фізкультури, 1.

\section{Information about the author}

Kulykovska Svitlana,

https:orcid.org/0000-0001-7061-5607,

kulikovskayasveta@gmail.com

National University

of Ukraine on Physical Education and Sport,

03150, Kyiv, Fizkul'tury str., 1. 